\title{
Sufism and the Indonesian Islamic Revival
}

\author{
JULIA DAY HOWELL
}

$\mathrm{L}$ LIKE OTHER PARTS OF THE MUSLIM WORLD, Indonesia has experienced an Islamic revival since the 1970s (cf. Hefner 1997; Jones 1980; Liddle 1996, 622-25; Muzaffar 1986; Schwarz 1994, 173-76; Tessler and Jesse 1996). To date, representations of Indonesia's Islamic revival have featured forms of religious practice and political activity concerned with what in the Sufi tradition is called the "outer" (labir) expression of Islam: support for and observance of religious law (I. syariah, A. syari'at), including the practice of obligatory rituals. Thus commonly mentioned as evidence of a revival in Indonesia are such things as the growing numbers of mosques and prayer houses, the increasing popularity of head coverings (kerudung, jilbab) among Muslim women and school girls, the increasing usage of Islamic greetings, the more common sight of Muslims excusing themselves for daily prayers and attending services at their workplaces, the appearance of new forms of Islamic student activity on university campuses, strong popular agitation against government actions seen as prejudicial to the Muslim community, and the establishment in 1991 of an Islamic bank.

This kind of representation of Indonesia's Islamic revival, however, fails to call attention to the increasing popularity of Islam's "inner" (batin $)^{1}$ spiritual expression, that is, to what I will call, following popular Indonesian contemporary usage, the

Julia Day Howell (J.Howell@mailbox.gu.edu.au) is a Senior Lecturer in the School of Asian and International Studies at Griffith University in Brisbane, Australia.

Research for this project was supported by Griffith University Research Grants. The author wishes to thank those who have provided invaluable introductions, personal knowledge, and insights into contemporary Indonesian Sufism, especially Djohan Effendi, Azyumardi Azra, Komaruddin Hidayat, Zamakhsyari Dhofier, Nasruddin Umar, Bambang Pranowo, Ace Partadiredja, Abdul Munir Mulkhan, James J. Fox, and the late Abdullah Ciptoprawiro. Particularly significant has been the assistance of Subandi, a collaborator on the author's early research on the Tarekat Qodiriyyah Naqsyabandiyyah and generous source of ongoing support. Helpful information for revisions to this paper came from the "Seminar Sufisme Perkotaan" mounted in January 2000 by Djohan Effendi, as head of the Agency for Religious Research and Development at the Indonesian Ministry of Religious Affairs, and from the September 2000 "Research Planning Workshop on Urban Sufism" organized by Griffith and the State Institute for Islamic Studies Syarif Hidayatullah, Jakarta, under the direction of its Rector, Azyumardi Azra, with funding from the Australia Indonesia Institute. The author is also grateful to the anonymous readers of the JAS for their perceptive and detailed comments.

${ }^{1}$ On the distinction between labir (I., J., from A. zabir) and batin (I., J., from A. batin) see Woodward (1989, 71-73).

The Journal of Asian Studies 60, no. 3 (August 2001):701-729.

(C) 2001 by the Association for Asian Studies, Inc. 
revival's "Sufi" side. ${ }^{2}$ Sufi-inspired forms of piety can be seen as complementary with "outer" (labir) expressions of Muslim religiosity, being practiced as additions to or enhancements of the fulfillment of the minimal requirements of the faith, ${ }^{3}$ but they may go unnoticed or be disregarded because of the polemic that surrounds them. Although Sufi piety has attracted a great deal of media attention in Indonesia, it has gone largely unremarked in Western scholarly accounts of contemporary Indonesian Islam. In effect, Indonesia's Islamic revival has been portrayed as "scripturalist," that is, as conforming to a conception of proper Muslim practice that rejects Sufi traditions as idolatrous accretions to the pristine faith and instead makes the execution of the obligatory prayers and observance of the law the whole of a Muslim's spiritual path.

In this essay, I argue that scripturalist piety is only part of the picture of Islamic revival in Indonesia in the latter twentieth century, and so the nature of Indonesian Islam at century's end has been seriously misunderstood. Contrary to expectations reasonably formed at mid-century that were based on assessments of the likely impacts of the changing educational system and of Muslim Modernist reformism, devotional and mystical intensifications of core Islamic practice-in short "Sufism"- - have survived. Indeed, they are being enthusiastically pursued, and not only by the elderly village men once thought to be Sufism's sole refuge in the twilight of its existence. Rather, Sufi devotionalism, including mystical practice, is alive and well in both country and city and has captured the interest of people who are well educated in the general education system - even members of the national elite. Moreover, Sufism, in diverse manifestations, has attracted people of both sexes who are still fully engaged in their careers, including some now in positions of considerable power. These new aficionados are reinterpreting Sufi thought as a source of inspiration for contemporary religious practice and are even becoming involved with long-established Suf

${ }^{2}$ Many different senses have been attached to the term "Suf," in Indonesia as elsewhere. Indeed, as explained below, the term "Sufi" did not come into common Indonesian language until the 1970s. My usage of the term here is quite broad and approximates that advocated by Chittick (1995) in his entry under "Sufism" in the Oxford Encyclopedia of the Modern Islamic World. There he resists the common Western practice of equating Sufism only with "Islamic mysticism" or "Islamic esotericism" and instead describes it as "the interiorization and intensification of Islamic faith and practice" $(1995,102)$. This allows us to recognize that devotional practices and religious concepts associated with Sufi traditions are often employed by Muslims as spiritual enhancements of their everyday lives, even when they are not undertaking a mystical path of dramatic personal transformation in hopes of direct experience of the divine. It also encompasses Muslim mystics independent of Sufi orders (tarekat) as well as those practicing within them. Nonetheless, Sufi orders (A. tariqah, I. tarekat), which have transmitted Islamic mystical knowledge through textual and practical instruction throughout the Muslim world, will feature prominently in this account of Indonesian Sufism. Also, the emphasis on personal intensification of faith and practices distinguishes my usage of "Sufism" here from an even broader usage (e.g., by Woodward 1989) covering any conventional cultural practice that can be identified with Sufi traditions by scholars (for example, pilgrimages to saints' graves and even selamatan, the Javanese ritual meal often described as "Hindu-Javanese" but identified by Woodward as manifesting Sufi elements seen in many Muslim cultures).

${ }^{3}$ It must be noted here briefly, in anticipation of subsequent discussion of Muslim Modernist critiques in the text, that not all Muslims have accepted this construction of Sufi practices as complementary with the performance of core obligations. Even before the twentieth century, there has been much controversy over which Sufi practices are lawful (cf. Drewes 1954; 1966; 1968; Florida 1995; Ricklefs 1998; Sartono 1966; Soebardi 1971; Zoetmulder 1995). Generally speaking, however, only those Sufi practices relating to the veneration of spiritual teachers have raised vehement objections because of their perceived likelihood of violating the doctrine of the oneness of God. Regimes of special prayers and fasting on their own have not raised the same concerns and are the most popular forms of engagement with "Sufism" today in Indonesia. 
institutions (the Sufi orders, or tarekat). In the towns and cities, there is also avid experimentation with new institutional forms designed to engage cosmopolitan Muslims, estranged from the social milieu of traditional Sufism, with Sufi learning and practice. These adaptations of Sufism are helping to soften contrasts between Modernist and Traditionalist styles of Islamic religiosity (a much remarked feature of the Islamic revival) and are an important but little-noted component of the liberal "Neo-Modernist" movement now enjoying prominence as the result of the election of one of its leading proponents, Abdurrahman Wahid, to the Presidency of the Republic.

This essay proceeds by sketching the parlous situation of Indonesian Sufism in the first part of the twentieth century, accounting for the predictions of scholars like Clifford Geertz (1960) and Soedjatmoko (1965) in the early years of the Republic that Sufism would fade from the social landscape, along with the "traditional" rural religious scholars who were its main proponents, as Indonesian society modernizes. I then provide evidence of the survival and new vitality of traditional Sufi institutions, the tarekat, in association with their usual institutional homes, the pesantren, or religious schools. Thereafter this essay gives attention to the re-engagement of urban intellectuals with Sufism in the early New Order period. Finally, it offers an overview of the institutional innovations of the 1980s and 1990s through which the middle and upper classes are now exploring "Neo-Sufism."

\section{Twentieth-Century Sufism: Never Lost but Newly Found}

\section{Sufism and the Pesantren}

It is generally agreed that Indonesian Islam before the twentieth century was predominantly Sufi, ${ }^{4}$ albeit of diverse theological orientations (Dhofier 1980, 30; Johns 1961, 14; 1995, 177; Ricklefs 1979, 107; 1998; Woodward 1989, 59), and that indeed the first proselytizers of Islam in Java, popularly remembered as the legendary Nine Saints (Wali Songo), were Sufis in the orthodox Ghazalian mold (Feener 1998).

${ }^{4}$ Anthony Johns $(1961 ; 1995)$ has argued that exponents of Sufi orders played a prominent role in the early propagation of Islam in Southeast Asia. Regardless of how important the tarekat were in early conversions, Sufi learning and practices soon became common in pesantren. Thus Nancy Florida observes, "Ngelmu tasawwuf (esoteric sciences), both practical and theoretical, pervaded premodern Islamic education in Java (as well as in most other areas of the Islamic world)" (1995, 346). From the pesantren, Sufi concepts and devotional practices (such as the labir-batin contrast, the possibility of self-realization of the divine, the ideal of the "Perfect Man," or insan kamil, and the veneration of saints) spread into the courts and the village sphere, where they became incorporated into local renditions of Islam, albeit with much variation over time and place (see Woodward 1989; Pelras 1993). The pervasiveness of Sufi influences in Indonesian Islam prior to the twentieth century has been repeatedly underscored in recent reappraisals of Dutch colonial and later "Orientalist" scholarship on premodern Javanese court culture (cf. Florida 1995; Ricklefs 1998; Sears 1996; Simuh 1987; 1988; Woodward 1996). This work has demonstrated that the courts, carriers of so-called "Hindu-Javanese" high culture from pre-Islamic times, were not, as often portrayed, culturally and socially distant from the pesantren, at least before the later nineteenth-century intensification of Dutch colonial administration. To the contrary, through intimate court-pesantren interactions, there occurred a deep Islamicization of Javanese culture and literature. These reassessments recognize that much of what had been identified as essentially "Hindu-Javanese" or "Hindu-Buddhist" religious culture is actually Sufi, and thus emphatically Islamic. 
Since perhaps the sixteenth century, ${ }^{5}$ the focal Muslim educational institutions in what is now Indonesia have been pesantren. ${ }^{6}$ These are teaching complexes consisting of (1) the domicile of a Muslim scholar (ulama, kyai) having at least some knowledge of theology, classical interpretations of the law, and Sufi knowledge (tasawuf); (2) a mosque; and (3) some residential facilities for those wishing to join the kyai in collective prayer and to enjoy his tutelage.

Today the most familiar form of pesantren is that described in Geertz's influential work, The Religion of Java (1960): it is the pesantren that educates children and youths and therefore provides accommodation primarily for them. Dhofier $(1980,30)$ and Madjid (1988, 104), however, argue that the earliest pesantren were primarily places for Sufi ritual practices by adults. People we could call "Sufis" (even though they might not be members of particular Sufi orders) would attend the pesantren to perform together both the obligatory prayers required of all Muslims and certain optional but meritorious prayers (dzikir and wirid). ${ }^{7}$ Only a few exceptional students were given instructions in the sacred texts. Over time, however, the emphasis on textual instruction of youths increased until that came to be the primary activity in most of the pesantren. Thus, by the eighteenth century the pesantren, which had served as the physical loci and social hubs of Sufi orders (I. tarekat, A. tariqab), in many cases also took on as a major function the education of young people in the basics of Islamic scholarship, including studies of the law (I. syariah, A. syari'at).

In the mid-nineteenth century, the easing of restrictions on the haj and the improved availability of transport greatly increased the number of Meccan-trained and well-qualified ulama, and so contributed to the rapid proliferation of both pesantren schools for children and the tarekat associated with them (Kartodirdjo 1966, 155). Particularly important in the rapid late nineteenth-century growth of the tarekat was the large number of ulama returning to the Indies after having studied with the charismatic Syekh Khatib Sambas, leader of the Qodiriyyah order, and Syekh Sulaiman

${ }^{5}$ This approximate date is suggested by Dhofier $(1980,31)$ and followed by Zulkifli (1994, 3 ) but depends on a loose construction of the institution and inference from historical evidence. Van Bruinessen (1992a, 76-77) puts the origins of the pesantren no earlier than the eighteenth century, and Kartodirdjo $(1966,155)$ holds that pesantren were not widespread until the nineteenth century, when larger numbers of returning pilgrims increased the numbers of ulama in Indonesia.

'In Java, pesantren are also called pondok ( literally, "bamboo hut"). In West Sumatra, comparable institutions are called surau and in Aceh, North Sumatra, they are called rangkang meunasab.

${ }^{7}$ Dzikir consists of repetitions of phrases containing the name of God, typically progressively shortened to rapid repetition of the final syllable. Being highly repetitive and rhythmical, $d z i k i r$ can stimulate altered states of consciousness under certain circumstances. In this way, it differs from the obligatory prayers, which generally do not have the same psychological potential. Thus, although dzikir is by no means always performed as part of a mystical quest (for example, it commonly constitutes part of the Idul Fitri holy day prayers performed by the whole community at the mosque), it is especially suited to that purpose. Wirid (I.) are short passages from the Qur'an, recited in Sufi practice before or after the dzikir, often repetitively. The recitation of particular wirid in specified numbers of repetitions may be assigned to aspirants by their spiritual director to meet their individual needs at certain times, whether for spiritual inspiration in their mystic quest or for a mundane purpose such as healing or protection. The notion that the wirid can help the practitioner access divine inspiration connects to the use of wirid in Javanese to mean "teaching" or "guidance." However, the wirid may also be given, much like an amulet, to anyone needing practical help, regardless of whether he or she has "higher" spiritual aspirations, and so in debased usages it grades into magical practices. 
Effendi, leader of the Naqsyabandiyyah order (Dhofier 1982, 141; Van Bruinessen 1992b).

In the early twentieth century, according to Zamakhsyari Dhofier (1980, 42-47), both the numbers of pesantren and of students enrolled in them continued to grow. However, the increasing availability over the course of the twentieth century of Western-style schooling and an expanding range of occupations available to Indonesians with such schooling in the longer run threatened the pesantren as centers of youth education. Although traditionally the major pesantren taught literacy (in Arabic and Malay) and, for the more advanced students, the analytical skills associated with Muslim jurisprudence, before the twentieth century none taught mathematics and science. ${ }^{8}$

By the 1910s, many pesantren started to expand their curriculum to include more secular subjects in a graded system of education (i.e., to add madrasab education). This proved attractive through the late colonial period when, despite the expansion of government primary education, higher levels of schooling were still beyond the reach of most native children (Kahin 1969, 31). The real challenge to the pesantren, then, came after Independence, when the new Republic started to develop governmentsupported Western-style education at all levels. The impact was severe, with smaller pesantren disappearing in the 1950s and 1960s, leaving only the major ones (Dhofier $1980,45 ; 1982,133)$. There has thus been reason to question the prospects of the pesantren in the latter twentieth century and beyond (cf. Abdullah 1986).

\section{The Challenge of Modernist Reformism}

Threats to the pesantren necessarily have also had implications for the tarekat, as the pesantren have been both the loci of the tarekat and important sources of recruitment for them, with former pupils returning later in life to their old pesantren, or to another in the pesantren network, to undertake more weighty spiritual regimes. But probably more significant to the continued vitality of the tarekat has been the direct challenge to Sufism posed by the reformist movements of the late colonial and republican periods. ${ }^{9}$ Of particular importance was Wahabism, a reform movement aimed at purifying the faith of local accretions and eliminating deviations from a narrow conception of the Oneness of God. Wahabism swept through the Indies in the nineteenth century, challenging many Sufi practices. Then, in the early twentieth century came the Muslim Modernist challenge, linking the task of purifying the faith to that of adapting it to modern times (Boland 1971; Hassan 1975, 19; Noer 1973; Peacock 1978). As Gellner (1984, 56ff), Geertz (1960, 183; 1968), and others have pointed out, Modernism has posed the most serious challenge to Sufism across the Muslim world. Modernists have seen in Sufism not only toleration of idolatrous folk rituals and the heretical assumption of divine powers by syekhs (to which older reformists also objected), but also offensively old-fashioned hierarchical relationships

${ }^{8}$ According to Florida, many pesantren did teach a variety of other subjects that could be said to form part of a secular curriculum: from Javanese literature and writing in Malay to "practical arts (including trade skills and magic practices), and fine arts" (1995, 346). Nonetheless, the pesantren curriculum was limited in subjects needed to enter the expanding range of twentieth-century white-collar positions.

${ }^{9}$ As demonstrated by Azra (1992), currents of Islamic reform moved through the Indies well prior to the nineteenth century, beginning as early as the second half of the seventeenth century. Many of these earlier movements, however, were efforts at the renewal and redirection of Sufism, which Azra calls "Neo-Sufi." 
that stifle independent thought in young students and impose unquestioning obedience on adult members of the orders (Noer 1973, 300). Sufism came to be known as "the Islam which is not Islam" (Islam yang bukan Islam).

Over the course of the twentieth century, the reformist rejection of Sufism has spread widely, promoted through such Modernist organizations as the Muhammadiyah. Those "strict" (sometimes called santri) Muslims associated with the Modernist movement came increasingly to define themselves in opposition to less committed and nominal Muslims (in Java, abangan or kejawen Muslims) ${ }^{10}$ as the politics of nation-building sharpened religious identities by incorporating them into political parties (Jay 1963; Boland 1971).

As conceptions of acceptable Muslim practice shifted over the course of the twentieth century, another site of tension that emerged was the mystical groups with roots in Sufism but only precariously identified with Islam. Some were not even explicitly identified with Islam at all. Latent within Sufism has always been the possibility that the Lord's "servant," in rapturous communion with the Lord, would lose all awareness of self and Other and experience identity with the Divine. Giving

${ }^{10}$ The utility of the terms santri and abangan in representing modes of Islamic religiosity in Java (and sometimes, awkwardly, in Indonesia more broadly) has been the subject of much debate since the terms were made popular in Western academic discourse through Geertz's The Religion of Java (1960). In that work, he presented santri and abangan along with priyayi as three religious orientations among Javanese people who were Muslims. (More than nine out of ten Javanese were Muslims at that time.) Reflecting Modernist Muslim views, he characterized the abangan and priyayi orientations as drawing far more heavily on Java's Indic and indigenous religious heritages than on Islam. The santri orientation, in contrast, stressed engagement with "strict" Islam (variously understood). These orientations were characteristic, as Geertz saw it, of groups commonly designated by those same terms. Thus the abangan were mostly peasants and the vast majority of the population. They differed from the priyayi, in this typology, in being more focused on ritual forms and magical practices deriving from the "Hindu-Buddhist" heritage. The priyayi, occupying the aristocratic and bureaucratic strata, had more of an intellectual style and hence stressed the mystical aspects of the "Indic" heritage. Since both the abangan and priyayi placed little emphasis on Islamic orthodoxy, as Geertz saw it, their credentials as Muslims appeared questionable. In contrast, the santri (concentrated in urban Javanese trading communities but also found in small numbers in the countryside) sent their children to the pesantren to study with ulama and to varying degrees attempted to follow Islamic law, even when it came into conflict with local custom.

Bachtiar (1973) and Koentjaraningrat (1985) have pointed out that Geertz's conflation of cultural orientations with status groups obscures the fact that there were "strict Muslims" in all social strata. Koentjaraningrat recommended abandoning the tripartite schema and retaining only the cultural contrast between santri (more overtly concerned with following the core obligations of Islam) and kejawen ("Javanist") Javanese, who would include both Geertz's abangan and priyayi. Woodward $(1989 ; 1996)$ goes further and challenges the construction of kejawen culture as "not really Islamic." He identifies the Islamic sources (largely Sufi) of both village and court ritual and of Javanese mysticism.

I have adopted Koentjaraningrat's sense of santri and abangan to indicate roughly contrasting variations in Javanese styles of Islamic religiosity, the former more focused on performance of core obligations and attempting to honor the syariah, the latter less so. This still allows recognition that santri may be more or less sympathetic to specialized Sufi learning (tasawuf), and that they may accept or reject particular nonobligatory rituals associated with the intense devotionalism of tarekats (especially $d z i k i r$ and wirid), whether in pursuit of mystical gnosis or not. We can then more readily understand that not all of those people who have been characterized as santri have associated themselves with the Modernist movement and that to the contrary the majority have not. Santri who have rejected the Modernist movement or remained untouched by it (sometimes, and increasingly, unfairly, characterized as kolot, or "old-fashioned) have for the most part been associated with the Nahdlatul Ulama, the nationwide association of ulama, founded in 1926. 
voice to such an experience, the tenth-century Persian Sufi mystic al-Hallaj declared, "I am God!" His spiritual brothers, regarding the ecstatic affirmation as heresy against the cardinal tenet that there can be "no seconds" to the One God, had him executed (cf. Massignon 1982). The Javanese tradition that one of the first walis, a certain Seh Siti Jenar, achieved such an ecstatic union with God and was similarly punished for the sin of speaking openly of it (Soebardi 1971; Florida 1995, 355-66; Sears 1996, 71-73) has been a reference point for heterodox Sufis for generations. ${ }^{11}$ The hallmarks of their heterodoxy, from the perspective of Ghazalian Sufis, are their acceptance of the possibility of, or intimation that they personally have achieved, identity with God; their consequent elevation of the mystical experience above the "outer" expressions of devotion to God, even to the extent of considering the law (syariab) merely a starting point for beginners; and an incomplete spiritual "genealogy" (silsilab) through which each teacher connects himself with his predecessors (in orthodox Sufism, in an unbroken line of properly initiated masters back to the Prophet Muhammed himself). In Java such heterodox Sufis might well trace their line of initiation back to one of the founding saints, particularly to Seh Siti Jenar, but not beyond; and pilgrimage to the graves of those saints on the northern coast of Java was held to be as good as a pilgrimage to Mecca (Woodward 1989, 101-08).

\section{Fracturing Identities}

Under pressure from Modernist reformist (that is, scripturalist) Muslims, such heterodox Sufis in the early decades of the twentieth century either abandoned identification with Islam (cf. Steenbrink 1996, 171) or claimed the independent superiority of "Islam Jawa" (Javanese Islam). ${ }^{12}$ Numerous so-called kebatinan (or mystical) groups began to form around gurus, ${ }^{13}$ some with past connections to Sufistyle masters and others informally schooled by parents and through participation in the religious life of the community in loosely Sufi Javanese practices of asceticism and meditation. The imagery and philosophies of the mystical groups of the period also reveal their founders' engagement with Christianity (through Dutch churches and schools), and with the archipelago's ancient Indic heritage (through the indigenous theater arts, especially the puppet theatre; through study groups like the Theosophical Society; and through books [Hadiwijono 1967; Stange 1986]). This eclecticism, associated with polytheism, was also offensive to Muslim reformists.

After mid-century, under the new Indonesian Republic, the mystical groups proliferated rapidly (Hadiwijono 1967, 216-17; Ricklefs 1979, 124; Van der Kroef 1961). Not only that, but they formed an association to promote their interests and began to press for acknowledgment as fully-fledged "religions" (agama) under the Constitution, on a par with Islam, Protestantism, and Catholicism, which had already,

${ }^{11}$ For a twentieth-century example, see Howell (1977). The fascination with Seh Siti Jenar is not confined to heterodox Sufis, however. Books on this wali appear regularly (for example, Mulkhan 1985). In 1989 a group of scholars at the State Islamic Institute in Yogyakarta even planned to stage a re-enactment of Siti Jenar's trial, with the eminent Prof. Dr. Simuh playing the head of the religious court and the self-styled Sufi writer Emha Ainun Nadjib appearing as Siti Jenar. The police, however, refused permission for the performance (Steenbrink 1996, 174).

${ }^{12}$ An example of the latter was the last guru of the founder of the Javanese Hindu sect Sadhar Mapan. See Howell (1977, 25-31, 71-72).

${ }^{13}$ Kebatinan (I., J.), from the root batin ("inner") means literally "inwardness;" hence kebatinan refers to "inward spirituality" or "mystical spirituality." 
in effect, received government acknowledgment by the establishment of departments in the Ministry of Religion dedicated to their support (cf. Howell 1982; Stange 1986). Some kebatinan groups, like Agama Adam Makrifat (The Religion of the PerfectlyRealized Adam) and Agama Sapta Dharma, went ahead and declared themselves "religions" regardless. ${ }^{14}$

\section{Demise of the Tarekat? Images of Decline and Signs of Renewal}

It is from this time, when rapid growth and increasing confidence of the independent mystical (kebatinan) groups coincided with the disappearance of many pesantren, that Geertz's ethnographies on Javanese religion date. This, then, is the context in which we must interpret his picture of pesantren life and Sufism. The tarekat, and so the institutional core of the Sufi tradition, appear as withering vestiges of the past, clinging to life through the persons of a few elderly peasant men and in imminent danger of dying out with them (Geertz 1960, 182-84). Under the pressure of decades of Modernist Muslim reformism, Islamic mysticism in its orthodox Suf form seemed to be disappearing, leaving "good Muslims" exclusively scripturalists. Those with a mystical bent, other than those fading rustics, no longer sought to develop it within Islam as Islam had come to be understood; instead the myriad mystical groups, mostly centered in cities, were attracting those who in times past would have been Sufi seekers.

This picture of the life of pesantren and the tarekat associated with them is under revision, however. It has become apparent that both of those institutions have a good deal more vigor than was once supposed by Western scholars. The continuing strength and adaptiveness of the pesantren was reported in a series of Indonesian governmentsponsored publications in the 1970s and 1980s, notably those of Prasodjo et al. (1974), Rahardjo (1974, 1985), Madjid (1977), and Dhofier (1982), and in several theses by Indonesians closely linked to the pesantren themselves (e.g., Dhofier 1980; Pranowo 1991a; Zulkifli 1994). Dhofier (1982, 40, 43) even reported an absolute growth in numbers of pesantren in Java between 1942 and 1978, from 1,871 to 4,195. Similarly, enrollments grew over the same period from just under 140,000 to just over 677,000 , showing a recovery from the slump of the 1950s and 1960s. The Department of Religion now puts the number of pesantren at 9,388 and the total number of students at over 1,770,000 (Departmen Agama R.I. 1997, ii).

Also, the journal Pesantren, first published in 1984, provided an academic forum for taking stock of the state of pesantren and considering what could be done to assure them a valued role in modern society. Magazines like Pesantren's Linkage $e^{15}$ and papers

${ }^{14}$ Subagya's “Daftar Aliran-Aliran Kepercayaan: Kebatinan, Kerohanian, Kejiwaan” (List of Faith Movements: Mystical Groups, Spiritual Groups, and Spiritual Psychology Groups), first published in the early 1970s ([1973] 1976, 129-38), still shows thirty-one groups calling themselves "Agama (or Igama) x, y, z . . . " He even lists seven still using "Islam" in the title (e.g., Islam Rasa Tunggal, and more boldly, Agama Islam Sebenarnya [The True Religion of Islam]). By this time, however, it had become illegal for spiritual groups to claim the full status of a religion (agama), and it was extremely dangerous to do so. It is likely that by the 1970 s those groups had already disappeared or no longer operated under names using the word agama. Thus, for example, the former Agama Sapta Darma became simply Sapta Darma, accepted registration as a kepercayaan ("faith" group administered by the Department of Education and Culture), and survived through to the end of the century.

${ }^{15}$ Published by The Indonesian Society for Pesantren and Community Development (P3M) in Jakarta from 1985 (title originally in English). 
sympathetic to "Traditionalist" Islam featured articles on the "modern" face of pesantren, with articles on the numerous institutions that were adding a graded curriculum up to the secondary and in some cases even tertiary level and undertaking a range of community development activities (rotating credit entrepreneurship, trials of new agricultural methods, etc.). As community development agents, pesantren have become an important part of the NGO sector.

More recently, a growing body of research on the Nahdlatul Ulama, the coordinating body for traditionalist Muslim scholars and their pesantren, has called attention to the continuing strength of this sector of Indonesian society, not just as a political force but, especially since the NU's withdrawal from party politics in 1984 , as a source of local community strength and cultural revitalization (cf. Jones 1984; Barton and Fealy 1996). Following the recent election of the NU's chairman, Abdurrahman Wahid, to the presidency of the Republic (its fourth, and the first freely elected president since the fall of former President Suharto's New Order government), the NU and the pesantren are likely to attract considerably more scholarly attention.

Although the primary focus of the literature on latter twentieth-century pesantren has been on their role as providers of schooling for youngsters and on their role, via the NU and party system, in national politics, several authors have emphasized the continuing importance of Sufism within the pesantren. Most notable in this regard are Dhofier $(1980 ; 1982)$, whose pivotal historical and ethnographic work demonstrates the intimate part Sufism (if not always Sufi orders) has played in pesantren life from its earliest days in Indonesia, and Van Bruinessen (1992b; 1995), who has chronicled the spread of both major and minor Sufi orders in Indonesia. Pranowo (1991a; 1991b) and Zulkifli (1994) provide further ethnographic case studies demonstrating the continuing importance of Sufism in the pesantren. Zulkifli argues that this can best be appreciated when it is recognized that Sufism consists in ascetic and devotional regimes that need not be part of a mystical path nor accompanied by advanced metaphysical studies. Many who join in the collective performance of the optional but recommended prayers associated with Sufism (dzikir and wirid) may not be members of a Sufi order. It then follows that even pesantren without a tarekat branch may conduct Sufi devotions and so carry on Sufi traditions.

In sum, scholarship on the pesantren appearing since the 1970s and 1980s shows that they are recovering in numbers and organizational vitality and that Sufism, far from being squeezed out as educational standards improve, continues as a valued part of pesantren life. One further indication of the survival of Sufism within the pesantren context is the founding in 1957 of an executive committee of tarekat leaders within the Nahdlatul Ulama to accredit orthodox Sufi orders and to monitor them for the maintenance of ethical standards. ${ }^{16}$ Nor was this a marginal body within the NU: according to Dhofier its "top elected leaders . . . have been the leading Kyai of major pesantren" (1980, 270). This clearly demonstrates the positive place of the Sufi tarekat within Indonesia's largest Muslim organization.

${ }^{16}$ The committee was first called the Pucuk Pimpinan Jami 'iyyah Abli Thoriqob Mu'tabarab; from 1979 it became the Jam 'iyyab Thoriqqob $M u$ 'tabarah Nabdiyyin after one faction split off and formed the JATMI (Jam 'iyah Abli Thariqah Mu' 'tabarah Indonesia) and began working through GOLKAR (Dhofier 1980, 270; Syam 1998, 41-43). Other principals of orthodox Sufi orders, like KH Sahibul Wafa Tajul 'Arifin (or "Abah Anom") of TQN Pesantren Suryalaya, have never joined either body. 


\section{Sufism as Part of the Islamic Revival: New Forms and Interpretations}

Sufism, both as a ritual activity and as a mystical path undertaken within orthodox orders, clearly has a firm place in Indonesian Islam in the latter part of the twentieth century. But it has done more than merely survive. Very much a contributor to the broader Islamic revival, Sufism too has undergone revitalization. As part of the broader revival, it has been subject to reinterpretations that have helped break down distinctions between "Traditionalists" and "Modernists"; numerous tarekat have experienced new growth, and new kinds of people have joined them, including cosmopolitan urbanites; and finally, Sufism has found expression through new institutional forms in urban environments.

\section{The Urban Rehabilitation of Sufism in the Early New Order}

As with scripturalist forms of Modernism and Islamist ideologies emanating from the Near East, Sufism attracted considerable interest among students, intellectuals, and artists from the 1970s. On the literary scene, Abdul Hadi announced in 1970 the eclipse of socialist realism with a new genre of "Sufi literature" (Aveling 2001, 229-33; Baidlawi 1987; Muhawar-Rahman 1991; Nurullah 1989). ${ }^{17}$ And in the later 1970 s and 1980s, Sufism, like other aspects of Islamic thought, moved out of the mosque and pesantren, even beyond the Islamic universities (the IAIN), and found a place on secular university campuses. It was a popular topic in the student-organized Islamic study groups at the Bandung Institute of Technology and Gadjah Mada University that played an important part in the Islamic revival among the younger generation and the urban middle classes. The new appeal of Sufism to these groups was also evident in the bookshops, where titles on Sufism became top sellers among books on Islam (cf. Effendi 1985; Abdullah 1996, 60; Mohammad et al. 2000).

Remarkably, among the popular titles were appreciative interpretations of Sufism by Muslim "Modernist" intellectuals. Notable among these were several books on Sufism by Hamka, a highly respected Muslim Modernist and a major figure in the Independence movement. In these he disengages the concept of tasawuf (in this context, the philosophical underpinnings of Sufi devotional practices) from the concept

${ }^{17}$ Aveling (2001, 229-33) credits such "established" New Order poets as Abdul Hadi, Taufiq Ismail, and Sutardji Caljoum Bachri with introducing the first Indonesian Islamic poetry for the growing numbers of Indonesians drawn into the Islamic revival since the 1970s. Hadi also translated the mystical Islamic writings of Rumi, Hafiz, and other Persian poets into Indonesian. However, it was a younger generation of poets born after Indonesian Independence, and mostly after 1960 (for example, Emha Ainun Nadjib, Ahmadun Yosi Herfanda, and Acep Zamzam Noor) who most compellingly conveyed the interiority of mystical experience in their poetry. Explicitly called "Sufis" by Indonesian contemporaries, they "wrote a type of verse that was youthful, light, playful, at ease with Koranic references as well as the names of the prophets and the Persian mystics.... There was almost a radiance to their descriptions of a world filled with the God whose beauty attracted spontaneous worship, who was everywhere and yet 'nearer to you than your jugular vein' "' (Aveling 2001, 233). Through their work, Aveling observes, by the 1980s "religious belief and experience had . . . become ... the most characteristic topic of poetic expression" $(2001,230)$. 
of tarekat (taken as the institutional form, a Sufi order). ${ }^{18}$ Thus in his classic Tasauf Moderen (Modern Tasawuf, [1939] 1990) and Tasauf: Perkembangan dan Pemurniannya (Tasawuf: Development and Purification, 1984), he warns that reforms aimed at the purification of the faith, particularly the expunging of devotions suspected of not being in conformity with the Qur'an and Hadiths, have for many resulted in a desiccation of their faith. Eschewing idolatrous local customs, people find themselves left with empty formalism: prayers said, poor-tax paid, haj undertaken, but simply in compliance with imposed requirements, without finding in them a deeper spiritual meaning. Hamka thus advocates cultivation of an inner spiritual life that is guided by the outer forms of conventional Muslim religiosity but that has a deeper emotional richness and, through cultivating introspection, a greater ethical subtlety. Tasawuf is represented as a body of Muslim knowledge that can help foster that inner life. In this way, he offers a construction of Sufism that rehabilitates it for modern cosmopolitans wary of the tarekat with their mysteries and vows of obedience to spiritual directors. Tasawuf, classically taught only to advanced devotees in the pesantren setting and principally to members of tarekat, becomes available in bookshops in the city and can be absorbed whenever the reader is able to devote time-perhaps at home, perhaps with friends or fellow students - to quiet reflection. ${ }^{19}$

Similar themes were developed in the 1970s and 1980s in the work of a younger generation of Muslim intellectuals then emerging into prominence (Hassan 1975, 117-77; Howell, Subandi, and Nelson 1997, 279; Woodward 1989, 137-40). ${ }^{20}$

${ }^{18}$ Tarekat can also be used in a broader sense to mean "austerities." Austerities like nonobligatory fasting are commonly practiced by members of Sufi orders but may also be practiced outside that context (cf. Woodward 1989, 171).

${ }^{19}$ Note, however, that these works, published originally in the 1930 s and continually in print since, do not use the word "Sufism" (I. "Sufisme"). That term did not enter popular usage until the 1970s, when European and North American publications (e.g., Nasr 1966; Nicholson 1975; and Trimingham 1973) using the word "Sufism" (or Germanic equivalents) in connection with what Indonesians had been calling tasawuf and tarekat appeared in quantities in Indonesian bookshops. Thus, when the research section of the Indonesian Department of Religion published a special edition of its journal Dialog entitled Sufisme di Indonesia ("Sufism in Indonesia") in March 1978, the opening essay began with a justification for using the term "Sufisme" in connection with tasawuf and tarekat (Mursyid 1978, 5). Interestingly, the use of that term in the title of one of the other essays in the volume, Moeslim Abdurrahman's "Sufisme di Kediri" ("Sufism in Kediri" [1978]), provoked some of its subjects, members of tarekats in Kediri, to challenge him on that usage, which they considered odd and inappropriate (personal communication).

${ }^{20}$ An example can be taken from Nurcholish Madjid's Modernisasi Ialah Rationalisasi Bukan Westernisasi, in which he writes: "The most beautiful and most profound emotion we can experience is the sensation of the mystical. It is the sower of all true science. He to whom this emotion is a stranger, who can no longer stand rapt in awe, is as good as dead. To know that what is impenetrable to us really exists, manifesting itself as the highest wisdom and the most radiant beauty which our dull faculties can comprehend only in their most primitive formsthis knowledge, this feeling is at the center of true religiousness" (1968, 5, cited and translated in Hassan 1975, 33). See also Madjid's "Menyegarkan Faham Keagamaan Dikalangan Ummat Islam Indonesia" ("Reinvigorating Religious Understanding in the Indonesian Muslim Community"), an historic talk given at the cultural center Taman Ismail Marzuki on 30 October 1972 and translated in full in Hassan (1975, 315-30). See especially p. 317, where he refers approvingly to an expression commonly used by Javanese mystics, "manunggaling kawula lan Gusti" or the "unification of a [sic] slave with his Lord," and speaks of faith (iman) as being properly cultivated through (inter alia) dzikir. In the mid-'80s, when tasawuf was gaining more notice among the general public, both Madjid and Djohan Effendi (another of the early and prominent Neo-Modernists and presently State Secretary in Abdurrahman Wahid's government) contributed appreciative articles on tasawuf to the journal Pesantren. Madjid (1985) wrote 
Variously identified as "Neo-Traditionalists" and "Neo-Modernists" since they reassessed and appreciated anew both reform and tradition, they included people of both Modernist and Traditionalist backgrounds, most notably the '60s Modernist student group (HMI) leader Nurcholish Madjid and Abdurrahman Wahid, leader of the Traditionalist Muslim Nahdlatul Ulama (NU) (now Indonesian President). Perhaps best known in Western scholarship for their liberal interpretations of Islamic law, these (let us say) "Neo-Modernists" nonetheless also have encouraged a new appreciation of Sufism as a way to develop the spiritual or "inner" (batin) meaning of religion (agama), very much along the lines suggested by Hamka. ${ }^{21}$

Moving up behind the intellectual avant-garde represented by Neo-Modernist Madjid has come the main body of the Modernist reform movement embodied in the Muhammadiyah. According to Abdul Munir Mulkhan, a leading figure in the dakwah (proselytizing) movement of the early New Order and a Muhammadiyah notable, there has been "a turning towards Sufism" in the Muhammadiyah. That organization, once the main critic of Sufism and "still allergic" to the tarekat, nonetheless recorded its affirmation of the importance of the inner, spiritual side of the faith at its national conference in 1995.22 This appreciation, said Mulkhan, ${ }^{23}$ has come partly from a realization of the shortcomings of the dakwah movement in convincing lax Muslims to set aside what reformists viewed as nonconforming customs, like the Sufi $d z i k i$ r and wirid. By channeling Muslims into a narrow formalism, it was failing to provide them with the emotional sustenance people look to their faith for. Mulkhan also alluded to a crisis in retaining the commitment of Muhammadiyah's own young people. When the santri youths gained access to universities in significant numbers for the first time in the 1980s, he observed, they found that their scripturalist approach to religion clashed with the circumstances they faced in pursuing their careers: should you ride the bus to class when you will be assaulted by the sight of women with

on "Tasawuf as the Essence of Religiosity" ("Tasawuf Sebagai Inti Keberagamaan"), and Effendi (1985) introduced the volume with his essay "Returning to Tasawuf" ("Kembali ke Tasawuf'). A decade later Taufik Abdullah commented on the connection between modernization, the post-1965 situation of young Indonesian intellectuals, the Neo-Modernist movement, and Sufism, noting that under the evolving circumstances, "Islam may have to depend on its mystical tradition and on the theological messages of the Qur'an" $(1996,177)$. He goes on to say, "By aiming at purity of heart in the effort to reach ultimate Truth, mysticism seeks to achieve authenticity of life, including life in all its mundane aspects. As its practitioners never fail to emphasize, Sufism is a genuine Islamic humanistic tradition that, while not preaching passivity, puts high value on mental and spiritual contentment" (1996, 177-78). See also Azra (2000a, 167) on Abdurrahman Wahid's "well-known . . conviction in Islamic mysticism which puts a strong emphasis on agnostic [sic., probably "gnostic"] knowledge (ilm al-ma'rifab) which in Islamic boarding schools is called ilmu laduni." This is illustrated in Azra's (2000b) explication of the significance of Abdurrahman Wahid's visit, in the first days of his presidency, to the tomb of the saintly K. H. Ahmad Mutamakin, whom Azra characterizes as a champion of "esoteric Islam" following in the line of Syekh Siti Jenar, Sunan Panggung, and Syekh Among Raga.

${ }^{21} \mathrm{Hamka}$, however, took exception to the direction in which Neo-Modernists like Madjid took the contextual approach to Qur'anic exegesis of the earlier Modernists (Hassan 1975, 180).

${ }^{22}$ See Materi Muktamar Mubammadiyah ke-43, p. 86, where, amongst numerous dakwah initiatives, the conference endorsed the following: "the development of community ritual life by leading prayers ( $\left(\sigma^{\prime} a\right)$ and $d z i k i r$ according to the sunnah, [and] leading shalat tahajut and shalat malam [optional prayers associated with Sufism] especially for strategic groups, [namely] the middle class, executives and managers in large cities, along with developing study of the deeper meaning of Islamic law using an intellectual approach."

${ }^{23}$ Interview with the author, July 1999. 
uncovered hair and calves? Perhaps you should walk instead, with eyes downcast . . . and then be hit by a car at the intersection! Facing these dilemmas, the santri university students lacked the means to reorient themselves to their faith by engaging with it at a deeper level. Hamka's unhinging of tasawuf from tarekat has helped resolve such problems and has now become a conceptual strategy commonly employed by cosmopolitan Muslims. ${ }^{24}$

Traditionalist scholars, although not as a group opposed to Sufism, have also been careful to counter negative stereotypes of it among cosmopolitans when taking their message to the public through the medium of popular books. Thus, as Woodward (1993) shows, recent NU commentaries on the Hadiths stress the importance of the inner spiritual state in which obligatory prayers are performed (appealing to cosmopolitans and challenging Modernist formalism) but also denounce the practice of asking blessings of spirits at saints' graves (technically idolatrous and also connected with the notion of "ignorant superstition").

These reassessments of Sufism by both Modernists and Traditionalists (including the Neo-Modernist avant-garde of both provenances) have helped win it a place in Indonesia's latest Islamic revival. They have also contributed to the softening of distinctions between the Modernist and Traditionalist religious orientations and to the further erosion of the old cultural contrasts between abangan and santri. ${ }^{25}$ The disengagement of tasawuf from tarekat has made it possible to incorporate devotional elements once thought of as Traditionalist into the Modernist spiritual repertoire. Similarly, by adding a deeper spiritual dimension to ritual and legal observances, modern reinterpretations of Sufism have helped to make Muslim piety more attractive to people outside of committed "strict Muslim" (santri) circles. The "greening" (penghijauan, i.e., Islamicizing) of Indonesia's nominal Muslims, then, far from excluding Sufism, is actually accelerating because of Sufism's participation.

\section{From Theory to Practice: Signs of Growth in the Tarekat}

The rehabilitation of Sufism as an intellectually and doctrinally defensible form of spirituality for the "modern" Muslim, combined with the enthusiasms of the wider Islamic revival, appears to be stimulating increased participation in that classic Sufi institution, the tarekat. The media picked up on this phenomenon in the late 1980s, reporting on the "rush to join tarekat" ("Kenapa Mesti Tarakat?" [1987, cover; 6$10]) .{ }^{26}$ More detailed research on individual orders is adding weight to these reports. Thus Abdurrahman (1978), who made a study of the Syatariyyah order in East Java

${ }^{24} \mathrm{Although}$ there are indications of a greater public appreciation of some aspects of Sufism amongst Muslim Modernists in recent years, Nakamura (1980) cautions that there has never been a simple rejection of the Sufi tradition across the board in Muhammadiyah. Rather, reason (akal), which is commonly understood by Western scholars of Islam to be compatible only with scripturalism, is seen in Muhammadiyah as requiring the guidance of a developed character (akblak) and ikblas (earnestness), which, according to his informants, can be cultivated through devotional practices like dzikir and wirid.

${ }^{25}$ This change in the cultural landscape of the nation has been documented by, among others, Barton, who states plainly: "In the fifties and sixties Indonesian Islamic thought could crudely, but reasonably accurately, be described in terms of the two major aliran, or streams, of Traditionalism and Modernism, but by the 1980s such terms were no more than inadequate, and vaguely passé, starting points in describing Indonesian Islamic thought" (1994, 143).

${ }^{26}$ For an example of more recent media coverage, see the magazine Gatra's "special report" on Sufism in the 30 September 2000 issue (46[6]). 
in 1977 , reported that numbers in that order had been low all through the Old Order but from 1966 began to grow rapidly. Similarly, Howell, Subandi, and Nelson (1998, 281 ; 1999) found that memberships in two central Javanese branches of the Qodiriyyah-Naqsyabandiyyah order centered on Pesantren Suryalaya, West Java, grew dramatically from the mid-1980s. An analysis of length-of-membership data drawn from those branches in 1990 showed that 94.4 percent of members had joined since 1984. The total number of respondents to this survey, when repeated in 1997 , increased from 480 to 677 , even though several local chapters previously surveyed could not participate. ${ }^{27}$

Although these reports of increased participation in tarekat are highly suggestive, they must nonetheless be taken with some caution, as the detailed studies focusing on individual orders cannot be read as fully corroborating media reports suggesting growing numbers across the board. Because of the highly important role of the syekhs as links in the transmission of spiritual knowledge, as spiritual guides, and as sources of blessings (berkab), the branches of the orders they head are probably more vulnerable than highly bureaucratized religious organizations to erratic fluctuations in memberships. Those with great personal appeal can attract large numbers of participants; but should the charismatic leader withdraw for any reason, numbers can melt away quickly.

The adroitness of a tarekat's leadership in managing its political and financial relations with the broader society can also be of crucial importance, and not all kyai manage this equally well. Many tarekat take advantage of the legitimation and protection provided by the national ulamas' association, the Nahdlatul Ulama, and this may be sufficient. Others have been able to do equally well, or even better, by working outside the NU and supporting GOLKAR (under Suharto's New Order, the dominant vehicle of political mobilization). Pesantren Suryalaya's branch of the Qodiriyyah-Naqsyabandiyyah order (TQN) is one of the best examples of this: building on a history of strong support for the central government under the Old Order when it joined forces against the secessionist Darul Islam movement operating in its region, in the New Order TQN became a strong GOLKAR supporter and enjoyed patronage at the highest levels of the national government. ${ }^{28}$ Tarekat Siddiqiyyah, although lacking a complete spiritual genealogy and therefore not recognized by the NU, nonetheless also supported GOLKAR in the 1977 elections and thereafter "began to be important and attract hundreds of followers" (Dhofier $1980,40) .{ }^{29}$

It is difficult, then, to know if growing memberships in a particular tarekat, or even in a few of them with sufficient visibility to attract comment from the media,

${ }^{27}$ In 1997 heads of the local chapters that did not distribute the questionnaires reported an additional 745 members in their groups. This indicates a total 1997 membership of 1,422, in comparison to a 1990 membership of 480, amounting to a near threefold increase in size if these other chapters, included in the first survey of 1990, are included in the figures for 1997 (Howell, Subandi, and Nelson 1999).

${ }^{28}$ TQN Suryalaya records include newspaper articles featuring the participation of many Jakarta dignitaries at its functions. Former Intelligence chief General Yoga Soegama is a practicing member of the order and has married his son to the daughter of the tarekat's principal, Abah Anom. There are also close connections between Pesantren Suryalaya and the Paramadina Institute, founded by Nurcholish Madjid. Paramadina organizes weekend retreats to Suryalaya for people studying tasawuf at the Institute. For an account of the history of the organization, including its political alignments, see Zulkifli (1996, 85-116).

${ }^{29}$ For a detailed discussion of the connections between the tarekat and election politics during the 1970s and 1980s, see Syam (1998). 
really do betoken a general trend. Nonetheless, it is reasonable to conclude, given our current understanding of the secure place of the Sufi orders within contemporary "Traditionalist" Islam, combined with Sufism's growing acceptability amongst intellectuals and the increasing piety among the Muslim population in general, that more than a few tarekat have experienced recent growth.

\section{A “New Breed" of Sufi: Increasing Diversity among Tarekat Participants}

If evidence of growth in memberships is still equivocal, a more compelling picture is emerging of new types of participants in the Sufi orders in the 1980s and 1990s. Geertz's ethnography of an East Javanese town and hinterland in the 1950s portrayed the tarekat as "a kind of old men's pondok" (1960, 182). Dhofier's 1970s observations of tarekat in Central and East Java were still in the main consistent with Geertz's characterization. Thus Dhofier reported that "the vast majority of the people who join the tarekat orders are old people who desire to intensify their religious faith" (1980, 261). Again, he emphasized, "The ethical and practical emphases of tarekat orders are on caring for the personal religious needs of the Javanese, particularly the old who have abandoned their worldly interests . . . the regular brotherly meetings serve the social needs of traditional people" (1980, 272).

Unlike Geertz, however, Dhofier did not regard the preponderance of elderly peasants with little or no formal education as a demographic marker of institutional decline. Particularly in his sketch of the small, provincial pesantren of Tegalsari in Central Java, he emphasized the importance of its tarekat in attracting to the preeminent "Religion of the Book" a largely unlettered and religiously untutored peasant populace. He recalled the historic role of tarekat, with their relatively simple rituals and camaraderie, in involving such people sufficiently to give them eventually a stronger basis in the faith, and he saw an ongoing need for this (Dhofier 1982, 12634). ${ }^{30}$

In one remarkable respect, however, the Sufi activities Dhofier observed in the 1970s, both at the large and renowned Pesantren Tebuireng and the minor pesantren Tegalsari, differed sharply from those observed by Geertz in the 1950s. At Tebuireng's weekly tarekat meetings, 40 percent were women (1980, 293); at Tegalsari, fully 60 percent of those associated with the tarekat were women $(1982,128)$. In Geertz's account, there had been no hint of such female enthusiasm for tarekat.

A similar strong representation of women appeared in the 1990s in the branches of Tarekat Qodiriyyah-Naqsyabandiyyah, Pesantren Suryalaya, surveyed by Howell and Subandi. In 1990 no less than 44.2 percent of the members of the Yogyakarta and Tegal branches (212 out of 480) were women (Howell, Subandi, and Nelson $1997,285)$. When surveyed in 1997 , these same branches overall included a smaller but still substantial component of women (32.5 percent, or 220 out of a total of 677 members surveyed) (Howell, Subandi, and Nelson, 1999).

${ }^{30}$ Although Dhofier emphasizes the importance of tarekat in reaching out to Muslims with little education in their faith, he is at pains to demonstrate that high levels of religious scholarship and sophistication in tasawuf have been available for centuries at the major centers of tarekat in the archipelago. The spread of religious sophistication, both in tasawuf and other branches of Islamic knowledge, has, however, been a gradual process and in the case of tasawuf, only a small inner core of scholars at certain pesantren specializing in tasawuf normally attempt high levels of mastery. The majority of tarekat participants, in his view, are concerned with the recommended additional rituals simply as forms of devotion. 
Again, caution is needed in extrapolating from limited cases, but there are nevertheless good reasons to suspect that women are now well represented in many tarekat. For one thing, the female presence in pesantren, which traditionally created the social networks through which people were recruited to the tarekat, has been growing. As Dhofier points out, although as early as 1885 L. W. C. Van den Berg had recorded the presence of girls in elementary religious instruction classes (pengajian) and in the pesantren, they were then limited to the beginner classes in pesantren $(1980,33)$. In the 1910s, when the more forward-looking pesantren began to incorporate secular subjects into their offerings and to experiment with graded education, some also began introducing dormitories for girls (Dhofier 1980,38). Pesantren catering to girls as well as boys are now common, even though girls are not quite evenly represented in such schools. Thus, in 1997 the Department of Religion records showed 725,089 girls in attendance at pesantren as compared to 906,341 boys (Department Agama RI 1997, ii).

The participation of women in tarekat may also be related to the growing importance of modes of recruitment other than via pesantren connections. This has clearly been the case with TQN Suryalaya since the mid-1980s, with campus, workplace, and political connections as well as news media and public talks all playing a role in introducing people, both women and men, to the order (Howell, Subandi, and Nelson 1997, 283-84). Ahmad Syafi'i, reporting on a 1990 team study of tarekat in the north coast heartland of Javanese Islam, similarly suggests the importance of new modes of recruitment in accounting for the success of the larger orders in that area. According to his periodization, from about the beginning of the century through the 1960s, when orthodox orders were supplanting older heterodox tarekat, initiation into an order followed on prior study in a pesantren, where the kyais could determine the suitability of the candidate to undertake the spiritual regime of the order. From the 1970s, the large orders began to open up and started to initiate anyone regarded as having some knowledge of Islam (Syafi'i 1996, 25). Thus, Syafi'i observed, "The result of this openness ... was that there were more and more tarekat groups and centers of activity. Now someone who is interested can easily join in the activities of a tarekat because they no longer operate like a secret mystical group but rather as a mass religious movement" (1996, 25).

This need not be interpreted as a weakening of standards in the tarekat, as the period of the opening up of the tarekat reported by Syafi'i coincides with the time when, under the New Order government, both secular schooling and religious instruction in the secular schools spread rapidly. Increasingly in the New Order, one need not have attended a pesantren to have a basic education in Islam. Moreover, both boys and girls have had equal access to religious instruction in the secular school system.

Changing modes of recruitment thus appear to have facilitated higher levels of participation by women in Sufi orders. But gender is not the only social attribute that is changing in the tarekat. Whereas both Geertz's 1950s fieldwork and Dhofier's 1970s participant observations led them to characterize the tarekat as a place of solace for poorly educated and elderly country folk, since the 1980s and 1990s well-educated middle-class people still active in their careers and living in urban environments have been joining too.

The TQN Pesantren Suryalaya surveys illustrate this point. More than half of the membership of the Yogyakarta and Tegal branches in the 1990s were less than fifty years old (60.5 percent in 1990 and 57.9 percent in 1997); and around one in five were under thirty (22.3 percent in 1990 and 19.2 percent in 1997) (Howell, Subandi, 
and Nelson 1997, 287; 1999). The member's educational backgrounds covered the full spectrum, remarkably including some with university-level studies (8 percent in 1990 and 6.5 percent in 1997), and their occupations ranged from pedicab driving and farming to university lecturing and other professional occupations (Howell, Subandi, and Nelson 1997, 289-90; 1999). Not surprisingly with these relatively high levels of education and occupation, as many as a quarter of the members (actually, 26.2 percent) were urban dwellers in 1990; in 1997 the proportion of urbanites had increased to just over a third (34 percent) (Howell, Subandi, and Nelson 1997, 288; 1999). While city people are still clearly in the minority in these tarekat branches, they are nonetheless an impressive presence in an institution once thought to be confined to rural environments.

Another tarekat group that has attracted attention for its high levels of welleducated urbanities is a branch of the Naqsyabandiyyah tarekat whose principal, Prof. Dr. Kadirun Yahya, M.Sc., is also a professor of physics and chemistry and an author of metaphysical treatises reconciling mystical experience with the sciences (see Thoyibi 1996). His combination of scientific erudition with a reputation for high spiritual accomplishments clearly appeals to the many university students and graduates in the group. Although this group's mode of initiation is more demanding and its activities are less accessible to casual participation than those of many tarekat, its recruitment patterns are nonetheless open in the sense that new members are drawn through nonpesantren contacts. Indeed, in the 1999 national election, enterprising young members of this group pioneered one of the more novel means of attracting new recruits: they actually formed a political party, Cinta Damai. While it was hardly a serious bid, its organizers were satisfied with the large number of new enquiries they received about the tarekat as a result of people reading Cinta Damai brochures. ${ }^{31}$

There is further evidence of middle-class participation in tarekat coming from studies of orders fully affirming the importance of Islamic law and self-identifying as "tarekat" but in some other respect having a weak claim on orthodoxy. Syafi'i distinguishes these borderline cases from "old-style" Javanist tarekat that regarded the syariah (Islamic law) as merely a kind of oversimplified rulebook for beginners and whose principals, without apology, traced their line of initiation back no further than the founding saints of Java. A common point of contention in the borderline cases is the validity of the tarekat principal's spiritual genealogy (silsilab). While normally the silsilah connects the master to the Prophet Muhammed via a chain of face-to-face initiations, there is a view that the Prophet can authorize the founding of an order by appearing to his chosen vessel in a dream. Such a line of spiritual authority is called a "silsilah Zahabiyah" (Syafi'i 1996, 21). Perhaps the most prominent such case is that of Tarekat Tijaniyah, whose credentials were debated by the NU tarekat leaders at two successive congresses (in 1988 and 1989) (Syaf'i 1996, 21). Tijaniyah has become one of the largest tarekat in Java in recent years and reportedly attracts substantial numbers of middle-class adherents.

More ambiguous yet is the status of an order founded on the basis of an exhortation delivered in a miraculous appearance of the Prophet to a devotee in a waking state, as happened to Maulana Syekh of Lombok on a visit to Mecca in the 1960s. This eventuated in the founding of the Tarekat Hizid Nahdlatul Wathan (Aziz 1996, 41). This movement, which Aziz classifies as a "pseudo-tarekat," has attracted "hundreds of thousands" of followers from all over Lombok and elsewhere in Indonesia, across

${ }^{31}$ This motive for forming the party was acknowledged to the author by organizers in the Yogyakarta branch in July 1999. 
the whole social spectrum: "young and old, ordinary people and intellectuals, traders, civil servants and professionals" (Aziz 1996, 43). Aziz portrays Maulana Syekh as a progressive educator, whose introduction of madrasab education into his pesantren (from 1943 for girls as well as boys) earned him great popularity and prominence. Aziz, however, also relates the attractiveness of the tarekat to its exceptionally loose entry requirements and fairly easy regime of spiritual practice $(1996,42)$.

\section{Tasawuf vs. Tarekat: Institutional Innovation in the 1990s}

While certain tarekat have been able to accommodate spiritual seekers with much more diverse social attributes and now recruit through many forms of social contact other than simply shared pesantren background, the tarekat have not entirely overcome their "image problems" with the secularly educated middle classes. The rehabilitation of Sufism by notable Muslim intellectuals, including Modernists, has helped to create a general interest in Sufism among educated urbanites, but social impediments remain. For one thing, there is a common set of prejudices against tarekat, according to which they are authoritarian and secretive institutions imposing demanding regimes of spiritual practices. Clearly this is not the whole story, nor are these features always seen in a negative light, since, as shown above, cosmopolitans do join tarekat that have some or all of these features. Nonetheless, such negative images of tarekat still deter some middle- and upper-class Muslims who have an interest in Sufism. For some, there are also problems of perceived social distance in seeking spiritual direction in rustic environments. Although the major tarekat, like Qodiriyyah Naqsabandiyyah and Syatariyyah, have chapters patronized by the most elite reaches of Indonesian society in Jakarta and other cities, these are not readily apparent or socially accessible to everyone.

In response to this situation of unmet need, Sufism has been adapted to a variety of new institutional forms in urban settings. Some of them build out from classic institutions, like the pengajian or tarekat, but modify them substantially; others utilize such international cultural forms as the "foundation," "institute," "seminar series," "intensive course," or "spiritual workshop." The danger of leaving behind conventional Muslim institutional forms in this way is that the spiritual activity will be suspected of being "really kebatinan," that is, a mystical or spiritual group not identified and fully in accord with the teachings of a single recognized religion (agama). ${ }^{32}$ Although kebatinan (strategically relabeled kepercayaan, or a "faith") has been recognized under national law since 1973 as a legitimate way of expressing the "Belief in One God" to which all Indonesians are committed under the Constitution, it has not fully escaped associations with occultism and even suspicion of antisocial tendencies (Howell 1982, 533; 1989, 153; Stange 1986). The new types of "Sufi" institutions of the 1990s avoid this association with kebatinan by explicitly presenting themselves as Muslim. Moreover, they put a clear emphasis on the importance of

\footnotetext{
${ }^{32}$ The close association of tarekat with kebatinan that once existed in popular consciousness is illustrated by Subagya's inclusion of twelve groups calling themselves "Tarekat [in various spellings] $\mathrm{x}, \mathrm{y}, \mathrm{z}$. . ." in his list of around two hundred and eighty "Aliran-Aliran Kepercayaan: Kebatinan, Kerohanian, Kejiwaan" ("List of Faith Movements: Mystical Groups, Spiritual Groups, and Spiritual Psychology Groups") (1976, 129-38). The list was compiled from disparate and not wholly reliable sources and was probably partly out of date already by the time of its initial publication (1973). Nonetheless, it shows that in the past, tarekat and kebatinan have been equated, either by the groups themselves or by others.
} 
Islamic law as a basis for Muslim spirituality and use Islamic texts, terminology, and symbolism in their activities.

An example of how conventional Muslim institutions adapt to accommodate new social needs is the Pesantren Daarut Tauhid, founded in 1987 in Bandung by Abdullah Gymnastiar (or "Aa Gym") and studied by Dindin Solahudin (1996). Daarut Tauhid is a conventional pesantren in the sense that it has a focal teacher (kyai) of the fundamentals of the faith, a mosque, and dormitories for students. It is unusual, however, in being founded by a young kyai who lacks a pesantren background himself and, indeed, who acquired his advanced knowledge by miraculous means. Further, Aa Gym has instituted a distinctly modern form of Sufi devotion not found in other pesantren. This is prayer accompanied by ritual weeping. Solahudin reports that Aa Gym in effect encourages the weeping, which is taken as a sign of repentance and piety, by leading communal prayers (both shalat, the obligatory devotions, and wirid, the optional, Sufi-style repetitive verses) in a dolorous voice and urging that the ritual be performed as a genuine expression of a felt emotional state. Likewise, in the freeform prayers (doa) following the wirid, Aa Gym also stimulates intense emotional involvement by recalling to the mostly youthful and middle-class congregations deep regret for succumbing to the temptations of urban society and falling away from piety. ${ }^{33}$ This type of ritual practice can be said to be "modern" and very much in the spirit of both Hamka's Tasauf Moderen and the NU's recent religious literature (cf. Woodward 1993, 571) insofar as it places emphasis upon the interior state (batin) that accompanies the outer ritual form (labir). However, expressing this through weeping, both in private and congregational worship, is unique to Pesantren Daarut Tauhid. ${ }^{34}$

Another example of the modification of traditional Sufi practices and institutions is the Kelompok Mujahadah (Mujahadah Group) studied by Aziz (1996) in Semarang and surrounding towns. "Mujahadah" is an easily learned Sufi practice involving wirid and dzikir in "an intense effort to become close to God and receive His blessing" (Aziz $1996,44)$. This practice, traditionally associated with funeral rituals but not restricted to that context, came to be done as a devotional practice on its own by small, informal groups of Muslims (mostly middle class) in the mid-1980s. Such groups became particularly popular in the 1990s when they received the blessing of a number of pesantren leaders and enjoyed the participation of a charismatic kyai whose attendance at a meeting would attract crowds of thousands. Despite the occasional involvement of a "traditional" charismatic figure in rituals drawn from the tarekat repertoire, however, these groups are quite novel in structure: they remain essentially informal gatherings, loosely networked together, with highly egalitarian relationships among participants. Their success, according to Aziz, is attributable to the freedom they afford: "freedom to attend or not to attend group activities, [and] freedom to do the ritual practices routinely or incidentally without feeling the loss of spiritual benefit" (1996, 49).

${ }^{33} \mathrm{KH}$ Hamdani Bakran Adz Dzaky, a graduate of the syariab faculty of the State Islamic Institute (IAIN) in Yogyakarta, has also molded his pesantren, Roudlatul Al Mutaqien, as the institutional base for a novel form of tasawuf tutelage attractive to students and teachers from the many high schools and universities in nearby Yogya. In addition to teaching little-known texts by Ibn al-Arabi, Kyai Hamdani also prescribes special prayers of his own composition to accompany the group $d z i k i$, and outside formal prayer times he joins some of his students in playing jazz on keyboard or guitar (Mohammad and Rahman 2000).

${ }^{34}$ There are, however, parallels in other religious traditions. W. A. Christian describes a fifteenth- and sixteenth-century Roman Catholic construction of tears as a gift of grace in his essay "Provoked Religious Weeping in Early Modern Spain" (1982). 
More distantly recalling traditional Muslim institutional forms, but still drawing on Islamic scholarship and devotional forms, are the proliferating "institutes," "foundations," "clubs," "intensive courses," "spiritual workshops," and the like that make Sufi traditions available through internationally standard forms. Perhaps the most outstanding example of this is Yayasan Wakaf Paramadina. Founded in Jakarta in 1986 by the eminent Neo-Modernist theologian and University of Chicago Ph.D. Nurcholish Madjid, the Paramadina is best known for its intellectual activities (cf. Hefner 1997). Indeed, it has served as an important center for intellectual exchange and religious education, offering short courses and public lectures in the area of "liberal Islam," Islamic studies, politics and Islam, religion and gender issues, comparative religion, and relations between religions. Located in the prestigious middle-class suburb of Pondok Indah, drawing on the services of professors from Jakarta's leading universities, and charging substantial fees for its courses and occasional lectures, Paramadina provides a congenial setting for well-to-do, cosmopolitan Muslims to explore their faith.

Paramadina, however, promotes a broader conception of spirituality than might be guessed from the Modernist background of its founder and its heavy intellectualist agenda. It also runs courses on "Tasawuf" and "Practical Sufism." Indeed the basic program of study offered by Paramadina is a three-part series: "Islam for Beginners" (twelve lectures), "Tawhid" (six lectures concerning the basic Muslim theological principle of the Oneness of God), and "Tasawuf" (six lectures on Sufi thought and practice). Recalling traditional pesantren policy, tasawuf is only available to those who have completed their study of the other two, more basic, subjects. The inclusion of tasawuf in the basic program of Paramadina nonetheless demonstrates the importance of Sufi inspiration in contemporary Neo-Modernist spirituality. ${ }^{35}$

Other similar venues for pursuing an interest in Sufism in a semi-academic environment in Jakarta include the Klub Kajian Agama (Religion Study Club), the Universitas Paramadinamulya, and ICNIS (Intensive Course and Networking for Islamic Sciences). The Klub Kajian Agama holds monthly seminars in a convention room with seating for several hundred at the Hotel Regent or another major hotel. It features two speakers (normally including Nurcholish Madjid) who talk on both religion and social issues and discuss points raised by the audience. The Universitas Paramadinamulya, like Paramadina, was founded by Madjid, but as a fully-fledged university with a variety of degree programs. ICNIS is an independent foundation operating out of the State Islamic Institute (IAIN) Syarif Hidayatullah's mosque.

${ }^{35}$ Paramadina's present director of programs, Budhy Munawar-Rahman, has also emphasized that talks on tasawuf are the most popular of the lecture programs offered there (personal communication). In speaking to reporters from Gatra, he described the situation as follows: "Usually about 40 people attend the lectures. But when it comes to talking about tasawuf, you can get as many as 120 people coming" (Wiranto, et al. 2000,1). This is reiterated by Hasbullah (2000, 41-43), who describes the Paramadina tasawuf offerings, as well as a range of other middle- and upper-class activities centering around the study and practice of Sufism, for example, the "Pesantren Eksekutif" ("Religious Training for Executives") held at the Bandung Giri Gahana Golf \& Resort in West Java. The popularity of "things Sufi" among the urban middle and upper classes is also illustrated by the publication of a monthly magazine entitled Sufi beginning in May 2000, and by the success that same year of a weekly Friday evening television program called Tasawuf on the NTV channel. The standard format for the television program was an interview by the host with a Muslim layperson who engaged in some kind of "Suf" spiritual practice or who had had some kind of impressive spiritual experience. An "expert" with formal academic qualifications, who was a Muslim but not a syech or ulama, would be asked to comment. 
Universitas Paramadinamulya and ICNIS both offer weekend nondegree courses on Islam, including tasawuf. The descriptions of the lecture topics in course brochures give a feeling for the emphasis on informed critical reflection and the value of that reflection as the basis of a more vital spirituality. This description of a lecture by Dr. Yunasril Alim, M.A., in the 1998 ICNIS lecture series on tasawuf is representative:

[Muslim] jurists use a formal legal approach in looking at the teachings of Islam, such that one gets the impression that God is, as it were, only a judge . . . theologians take a rational approach to the teachings of Islam, giving the impression that God is utterly transcendent, far from and way above all His creatures. But if we rely on rationality alone, we will never feel real religious fulfillment. Tasawu offers a spiritual approach to the teachings of Islam, and God is pictured as ever so near to humanity, like the beloved who gives warmth, peace and happiness when we are by His side. Under the title "The Structure of Tasawuf' this lecture will look at the form of Sufi teachings and ... what is meant by tasawuf' amali [the way of charity and good works, including required and meritorious prayers and fasting], tasawuf akblak [the way of ethical study and self-reflection], tasawuf ibadab [the way of pious observance and right action according to religious law], and tasawuf nazhari (falsafi) [spiritual enrichment through philosophical enquiry.$^{36}$

Alongside these institutions offering formal programs of study of tasawuf are numerous others more oriented to devotional practice and support for private spiritual development based on Sufi teachings. These include the Pusat Pengembangan Tasawuf Positif dan Klinik Spiritualitas Islam (Center for the Development of Positive Tasawuf and Clinic for Muslim Spirituality), the Sufi Healing Group operating out of the Fathullah Mosque on the IAIN Syarif Hidayatullah campus, and the Indonesian Islamic Media Network (IiMAN). The classes, workshops, and retreats run by these organizations attract people with comfortable incomes and relatively high levels of education. A similar organization, Yayasan Taskiya Sejati, headed by a relative of a former vice-president, provides a forum for government officials, high-ranking military officers, and rich business people to use Sufism as a part of their Muslim faith. The anomalous Yayasan Salamullah resembles a tarekat in that it focuses on a remarkable spiritual leader, but its tarekat status is shaky due to the extraordinary circumstances of its founding and unusual practices: its head, Lia Aminuddin, was visited by the Angel Gabriel and since then channels for him to her group. As a consequence, the neutral institutional format of yayasan (foundation) offers a better platform for the association of devotees and articulates other activities, such as the publication of their magazine, Lentera Islam.

To call attention to the distinctiveness of these new manifestations of Sufism from older, sometimes objectionable, Sufi forms, proponents and observers variously identify them with terms like "Neo-Sufi," "Tasawuf Positif," and "Practical Sufism." Although each usage points to somewhat different emphases, the terms nonetheless suggest a core of common features: an Islamic spirituality that infuses ritual forms with personal emotional meaning; an interpretation of Islam's ascetic and mystical traditions in ways that encourage full engagement in everyday social life (hence, a "positive" attitude to work in the world); and the innovation of social forms that

${ }^{36}$ This excerpt is from p. 25 of the brochure for "Islamic Study Packages" (Paket Studi Islam) offered from May to August 1998 by the organization ICNIS (Intensive Course and Networking for Islamic Sciences) [name originally in English]. The course descriptions were also carried on the organization's web site: www.icnis.or.id. 
support spiritual practice without imposing requirements for obedience to a spiritual master. It is Sufism that can be detached from the tarekat and used by "modern people" to cope with the uncertainties of a rapidly changing world. To the extent that it is mysticism, say its advocates, it is "this worldly" mysticism. ${ }^{37}$

\section{Conclusions}

Sufism, once strongly associated with the "traditional" rural sector of Indonesian society, clearly has not died out. The rural institutional bases of classical Sufism, the pesantren and tarekat, are intact and even show signs of vigorous growth associated with adaptive changes in structure, recruitment styles, and memberships. And, ironically, precisely in the period of Indonesia's most rapid economic development under the New Order government, Sufism has inspired new enthusiasm, even in the sectors of Indonesian society most intensely engaged in modernization and globalization: the urban middle and upper classes. This interest is expressed through the participation of urbanites in the long-established, rural-based Sufi orders, the tarekat, but also through novel institutional forms in the towns and cities. Further, the intellectual basis of Sufism is being discovered by cosmopolitans, and the tradition is being sympathetically reformulated, especially by Neo-Modernist intellectuals better known for their work on Islamic law in modern society.

Sufism, then, is very much a part of the wider Islamic revival that heretofore has been characterized in Western scholarship largely in scripturalist terms. A fervent concern on the part of Muslims of both Traditionalist and Modernist backgrounds to infuse "outward" expressions of faith (so strongly stressed in scripturalism) with an "inner" meaning and experiential richness by drawing on Islam's mystical tradition has been largely overlooked. Sufism, however, in its various manifestations, has played an important part in inspiring increased commitment to "outer" acts of piety that feature so prominently in accounts of Indonesia's Islamic revival. Sufism has also contributed to the softening of contrasts in religiosity associated with Islamic Traditionalism and Modernism and therefore helped create the common ground in civil society upon which political tensions, so acute in the period since the fall of the Suharto regime, can, it is hoped, be resolved. Neo-Sufism in particular is strongly linked with Neo-Modernist liberalism, not only because it is often espoused by the same thinkers, but because Neo-Sufi practice, with its emphasis on felt connection with the Divine as a basis for ethical social prescriptions, strongly reinforces tolerance for religious pluralism.

These findings have implications for the broader sociology of Islam, which presently is dominated by Gellner's characterization of Sufism in Muslim majority

${ }^{37}$ This type of reformed Sufism draws importantly on the writings of the Pakistani intellectual Fazlur Rahman, who has developed the concept of "Neo-Sufism" and with whom Nurcholish Madjid studied at the University of Chicago (cf. Barton 1991, 81; Syukur 1999, 139-44). Note, however, that what Rahman (1968, 239; 1970, 640), Azra (1992), and Voll (1994, 27-29) call "Neo-Sufism" dates back to the eighteenth century (in Voll's view) or even beyond (in Rachman's and Azra's constructions) and can only be seen as a precursor of contemporary Indonesian "Neo-Sufism." These authors refer to currents of Sufi thought that share with contemporary Indonesian Sufism the explicit concern with orthodoxy (being aligned with what is here called "unity" rather than "identity" mysticism) and advocating engagement with society rather than withdrawal from it. Nonetheless, Rachman's and Voll's premodern exemplars of "Neo-Sufism" were organizationally conventional. 
countries as fatally implicated in disappearing rural social formations. ${ }^{38}$ The validity of this view needs to be further examined through a reappraisal of the recent revival experiences of other Muslim countries. In so doing, it will be important to assess the extent to which representations of Islamic religiosity are colored by the affinity of scholars for models of modernization that foretell the demise of religion, or faced with its unexpected persistence, for "bookish" and "rational" styles of religiosity such as are found in Islamic Modernism.

Returning to the Indonesian case, given that this essay is concerned with trends, it is appropriate to conclude with some speculation as to the likely future of Sufism there. Bearing in mind the conditions that have fostered its survival up until now, it is reasonable to expect that Sufism will continue to be an important part of Indonesian life as long as certain features of the political and social environment of religion remain in place. These include the requirement for all Indonesians to practice one of five recognized religions (agama) $)^{39}$ or a "faith" (kepercayaan/kebatinan) with significant legal support behind the religions and significant opprobrium still attached to kebatinan. The relaxation of attitudes toward kebatinan would erode the attraction of Sufism as "fully legitimate" mysticism and encourage the proliferation of syncretic and highly privatized forms of "alternative" spirituality. Beyond the issue of restricted scope for the social construction of religiosity is that of actual funding. Continued heavy government financial support for religious education and religious projects of all sorts will likely favor Sufism to the extent that it keeps spiritual concerns central to concepts of Indonesian citizenship and promotes the means to engage with specifically Islamic spirituality. Also, since enthusiasm for Sufism is part of the overall Islamic revival, the continued importance of Islam to Indonesians (as to Muslims elsewhere in the world) as a cultural counterweight to Westernization should be propitious. If, however, sensitivities to Westernization should escalate, and for other reasons "fundamentalist" Islamist movements achieve political dominance in Indonesia, the prospects for Sufism would become decidedly poor. As for Neo-Sufism, continued economic and social development is likely to favor it over older Sufi expressions but not lead to their replacement by it, since, as we have seen, even the orthodox tarekat can be attractive to well-educated Muslims. Those tarekat with the best prospects for urban support are those whose principals are sufficiently comfortable with urban culture to put at ease people coming from the nonreligious education system and who operate relatively openly. With the increasing integration of pesantren and general education and the increasing penetration of urban culture into all areas of life, there should be no shortage of such leadership.

\section{List of References}

Abdullah, Taufik. 1986. "The Pesantren in Historical Perspective." In Islam and Society in Southeast Asia, edited by Taufik Abdullah and Sharon Siddique. Singapore: Institute of Southeast Asian Studies.

${ }^{38}$ The author addresses this theme in a forthcoming essay.

${ }^{39}$ The original Presidential Decision, No. 1, 1965, relating to this matter recognized six religions, not five: Islam, Catholicism and Protestantism (listed separately), Hinduism, Buddhism, and Confucianism. Confucianism was very soon administratively downgraded because of its association with a particular ethnic group and the divisiveness that supposedly could be provoked by that. Since the end of the Suharto era, however, Confucianism has recovered much of its original status under law. 
1996. "The Formation of a New Paradigm: A Sketch on Contemporary Islamic Discourse." In Toward a New Paradigm: Recent Developments in Indonesian Islamic Thought, edited by M. R. Woodward. Tempe: Arizona State University Program for Southeast Asian Studies.

Abdurrahman, Muslim. 1978. "Sufisme di Kediri" [Sufisim in Kediri].

Deparmen Agama Republik Indonesia. Dialog (special edition):23-40.

Aveling, Harry, ed. and trans. 2001. Secrets Need Words: Indonesian Poetry, 19661998. Southeast Asia Series No. 105. Athens: Ohio University Center for International Studies.

AzIZ, ABDul. 1996. "Praktek Pseudo-Tarekat: Memeluk Tradisi di Alam Modern"

[Pseudo-tarekat practices: Embracing tradition in the modern world]. Dialog, Jurnal Studi dan Informasi Keagamaan 44:35-50.

AzRA, Azyumardi. 1992. “The Transmission of Islamic Reformism to Indonesia:

Networks of Middle Eastern and Malay-Indonesian Ulama in the Seventeenth and Eighteenth Centuries." Ph.D. diss., Columbia University.

- 2000a. "In Search of the Man behind the Image." Understanding Gus Dur. Jakarta: The Jakarta Post Press.

- 2000b. "Mistifikasi Politik Indonesia di Awal Milenium Baru: Gus Dur dan K. H. Ahmad Mutamakin" [Mystification of Indonesian politics at the beginning of the new millennium: Gus Dur and K.H. Ahmad Mutamakin]. In Seribu Tabun Nusantara, edited by J. B. Kristanto. Jakarta: Kompas.

BACHTIAR, H. 1973. "The Religion of Java, A Commentary." Majalab Ilmu-Ilmu Sastra Indonesia 5:85-110.

Baidlawi, Masduki. 1987. "Mencari Sufi di Balik Puisi” [Seeking Sufism in poetry]. Editor 3(1):65.

Barton, Greg. 1991. "The International Context of the Emergence of Islamic NeoModernism in Indonesia." In Islam in the Indonesian Social Context, edited by M. Ricklefs. Clayton, Victoria: Monash University Centre of Southeast Asian Studies. 1994. "The Impact of Neo-Modernism on Indonesian Islamic Thought: The Emergence of a New Pluralism." In Democracy in Indonesia, 1950s and 1990s, edited by David Bourchier and John Legge. Melbourne: Monash University Centre of Southeast Asian Studies.

Barton, Greg, and Greg FeAly, eds. 1996. Nabdlatul Ulama, Traditional Islam, and Modernity in Indonesia. Melbourne: Monash Asia Institute.

Boland, B. J. 1971. The Struggle of Islam in Modern Indonesia. The Hague: Martinus Nijhoff.

Chittick, William C. 1995. "Sufi Thought and Practice." In The Oxford Encyclopedia of the Modern Islamic World, edited by John Esposito, vol. 4. New York: Oxford University Press.

Christian, W. A. 1982. "Provoked Religious Weeping in Early Modern Spain." In Religious Organization and Religious Experience, edited by J. Davis. New York: Academic Press.

Departmen Agama R. I. 1997. Data Poiensi Pondok Pesantren Selurub Indonesia [Data on the capacities of pondok/peasantren throughout Indonesia]. Jakarta: DirJen Pembinaan Kelembagaan Agama Islam, Direktorat Pembinaan Perguruan Agama Islam, Departmen Agama Republik Indonesia.

Dhofier, Zamakhsyari. 1980. "The Pesantren Tradition: A Study of the Role of the Kyai in the Maintenance of the Traditional Ideology of Islam in Java." Ph.D. diss., Australian National University, Canberra. 
1982. Tradisi Pesantren: Studi Tentang Pandangan Hidup Kyai [The peasantren tradition: A study of the views of a traditional Muslim religious scholar]. Jakarta: Lembaga Penelitan, Pendidikan dan Penerangan Ekonomi dan Sosial.

Drewes, G. W. J. 1954. Een Javaanse Primbon uit de Zestiende Eeuw [A Javanese primbon of the seventeenth century]. Leiden: E. J. Brill.

— 1966. "The Struggle between Javanism and Islam as Illustrated by the Serat Dermagandul." Bijdragen tot de Taal-, Land-en Volkenkunde 122(3):309-65.

- 1968. "Javanese Poems Dealing with or Attributed to the Saint of Bonan." Bijdragen tot de Taal-, Land-en Volkenkunde 124(2):209-40.

Effendi, Djohan. 1985. "Kembali ke Tasawuf' [Return to tasawuf]. Pesantren 2(3):2.

Feener, R. Michael. 1998. "A Re-examination of the Place of al-Hallaj in the Development of Southeast Asian Islam." Bijdragen tot de Taal-, Land-en Volkenkunde 154(4):571-92.

FLORIDA, NANCY. 1995. Writing the Past, Inscribing the Future: History as Prophecy in Colonial Java. Durham: Duke University Press.

Geertz, Clifford. 1960. The Religion of Java. Glencoe, IL: Free Press. . 1968. Islam Observed. Chicago: University of Chicago Press.

Gellner, Ernest. 1984. Muslim Society. Cambridge: Cambridge University Press. Hadiwijono, H. 1967. Man in the Present Javanese Mysticism. Baarn, The Netherlands: Bosch and Keuning.

HamKA. [1939] 1990. Tasauf Moderen [Modern tasawuf]. Jakarta: Pustaka Panjimas. 1984. Tasauf: Perkembangan dan Pemurniannya [Tasawuf: Development and purification]. Jakarta: PT Pustaka Panjimas.

Hasbullah, Moeflich. 2000. "Cultural Presentation of the Muslim Middle Class in Contemporary Indonesia." Studia Islamika 7(2):1-53.

Hassan, Mohammed Kamal. 1975. "Contemporary Muslim Religio-Political Thought in Indonesia: The Response to 'New Order Modernization."” Ph.D. diss., Columbia University.

Hefner, Robert W. 1997. "Islamization and Democratization in Indonesia." In Islam in an Era of Nation-States, edited by R. W. Hefner and P. Horvatich. Honolulu: University of Hawai'i Press.

Howell, Julia Day. 1977. "Vehicles for the Kalki Avatar: The Experiments of a Javanese Guru in Rationalizing Ecstatic Religion." Ph.D. diss., Stanford University.

- 1982. "Indonesia: Searching for Consensus." In Religions and Societies: Asia and the Middle East, edited by Carlo Caldarola. The Hague: Mouton.

- 1989. "States of Consciousness and Javanese Ecstatics." In Creating Indonesian Cultures, edited by Paul Alexander. Sydney: Oceania Press.

Howell, Julia Day, Subandi, and Peter L. Nelson. 1998. "Indonesian Sufism, Signs of Resurgence." In New Trends and Developments in the World of Islam, edited by Peter B. Clarke. London: Luzac Oriental.

- 1999. "Sufism and Cosmopolitanism: A Demographic Profile of Tarekat Qodiriyyah Naqsyabandiyyah, Pesantren Suryalaya, in the 1990s." Paper presented at the Annual Meeting of the Association for the Sociology of Religion, Chicago, August 5-7.

JAy, Robert T. 1963. Religion and Politics in Rural Central Java. Cultural Reports Series no. 12. New Haven: Yale University South-east Asia Studies.

Johns, ANThony. 1961. "Sufism as a Category in Indonesian Literature and History." Journal of Southeast Asian History 2(2):10-23. 
1995. "Sufism in Southeast Asia: Reflections and Reconsiderations." Journal of Asian Studies 26(1):169-83.

Jones, S. R. 1980. “'It Can't Happen Here': A Post-Khomeni Look at Indonesian Islam." Asian Survey: 20(3):311-23.

- 1984. "The Contraction and Expansion of the 'Umat' and the Role of the Nahdlatul Ulama in Indonesia." Indonesia 38:1-20.

KAHIN, G. 1969. Nationalism and Revolution in Indonesia. Ithaca: Cornell University Press.

Kartodirdjo, SARtono. 1966. The Peasant Revolt in Banten of 1888. s'Gravenhage, The Netherlands: M. Nijhoff.

"Kenapa Mesti Tarekat?" [Why tarekat?] 1987. Amanab 36 (20 Nov.-3 Dec.).

Koentjaraningrat, R. N. 1985. Javanese Culture. Singapore: Oxford University Press.

Liddle, R. William. 1996. "The Islamic Turn in Indonesia: A Political Explanation." Journal of Asian Studies 55(3):613-34.

Madjid, Nurcholish. 1977. "Pondok Pesantren 'Darul Ulum' di Rejoso, Peterongan, Jombang, Jawa Timur" [The pondok/pesantren "Darul Ulum" of Rejoso, Peterongan, Jombang, East Java]. Bulletin Proyek Penelitian Agama dan Perubahan Social. Jakarta: LEKNAS, LIPI.

- 1985. "Tasawuf Sebagai Inti Keberagamaan" [Tasawuf as the essence of religiousity]. Pesantren 2(3):3-9.

- 1988. "Tasauf dan Pesantren." In Pesantren dan Pembabaruan [Tasawuf and the pesantren], edited by M. Dawam Rahardjo. Jakarta: LP3ES.

Massignon, Herbert. 1982. The Passion of al-Hallaj, Mystic and Martyr of Islam. Vol. 1. Translated by Herbert Mason. Princeton: Princeton University Press.

Mohammad, Herry, Asrori Karni, Kholis Bahtiar Bkri, and Mujib Rahman. 2000. "Sufisme Merambah Kota Mengikat Umat" [Sufism spreads in the city, binding Muslims together]. Gatra 46(6):http://www.gatra.com/VI/46/ LKH1-46.ht.

Mohammad, Herry, and Mujib Rahman. 2000. “Ada Wirid Ada Jazz" [Where there's chanting, there's jazz]. Gatra 54(6):http:/www.gatra.com/VI/46/LKH246.ht.

Mulkhan, Abdul Munir, ed. 1985. Seb Siti Jenar dan Ajaran Wibdatul Wujud [Seh Siti Jenar and the Wahdatul Wujud Teaching]. Yogyakarta: Persatuan.

Munawar-Rahman, Budhy. 1991. "Puisi-puisi Perenial Emha Ainun Nadjib dan Pemikiran Islam Indonesia" [The perennialist poetry of Emha Ainun Nadjib and Indonesian Islamic thought]. Horison 7(29):7-17.

Mursyid, Hasybullah. 1978. "Sufisme; Sebuah Ulasan Singkat" Sufism di Indonesia [Sufism; A brief commentary]. Jakarta: Badan Penelitian dan Pengembangan Agama, Department Agama R. I.

Muzaffar, C. 1986. "Islamic Resurgence: A Global View (with Illustrations from Southeast Asia)." In Islam and Society in Southeast Asia, edited by T. Abdullah and S. Siddique. Singapore: Institute of Southeast Asian Studies.

Nakamura, M. 1980. "Unsur Sufi dalam Muhammadiyah? Catatan dari Kancah" [Sufi elements in Muhammadiyah? Notes from the field]. Prisma 9(8):92-98.

NAsR, S. H. 1972. Sufi Essays. London: Allen and Unwin.

Nicholson, R. A. 1975. The Mystics of Islam. London: Routledge and Kegan Paul. Noer, Deliar. 1973. The Modernist Muslim Movement in Indonesia, 1900-1942.

Singapore: Oxford University Press. 
Nurullah, Ahmad. 1989. "Sufisme dan Puisi Indonesia '80-an" [Sufism and Indonesian poetry of the "80s]. Unpublished paper presented to the "Dialog Penyair Jakarta," Dewan Kesenian Jakarta, 7-8 November.

PeAcock, J Ames. 1978. Muslim Puritans: Reformist Psychology in Southeast Asian Islam. Berkeley: University of California Press.

Pelras, Christian. 1994. "Religion, Tradition, and the Dynamics of Islamization in South Sulawesi. Indonesia 57(April):133-54.

Pranowo, M. B. 1991a. "Creating Islamic Tradition in Rural Java." Ph.D. diss., Monash University.

- 1991b. "Traditional Islam in Contemporary Rural Java. The Case of Tegal Rejo Pesantren." In Islam in the Indonesian Social Context, edited by M. Ricklefs. Clayton, Victoria: Monash University Centre of Southeast Asian Studies.

Prasodjo, S., et al. 1974. Profil Pesantren: Laporan Hasil Penelitian Pesantren AlFalak dan Delapan Pesantren Lain di Bogor [Pesantren profile: Research reports on the pesantren Al-Falak and eight other pesantren in Bogor]. Jakarta: LP3ES.

Rahardjo, M. Dawam, ed. 1974. Pesantren dan Pembabaruan [Pesantren and renewal]. Jakarta: LP3ES.

- ed. 1985. Pergaulatan Dunia Pesantren [Struggle in the pesantren world]. Jakarta. LP3ES.

Rahman, FAZlur. 1968. Islam. Garden City, NY: Doubleday-Anchor.

- 1970. Cambridge History of Islam. Vol. 2. Cambridge: Cambridge University Press.

RiCKlefs, M. C. 1979. "Six Centuries of Islamicization of Java." In Conversion to Islam, edited by N. Levtzion. New York: Holmes and Meir.

-1998. The Seen and Unseen Worlds in Java, 1726-1749: History, Literature, and Islam in the Court of Pakubuwana II. Honolulu: University of Hawai'i Press.

Sartono, Kartodirdjo. 1966. The Peasants' Revolt in Banten in 1988. The Hague: Martinus Nijhoff.

Schwarz, AdAM. 1994. A Nation in Waiting: Indonesia in the 1990s. Sydney: Allen and Unwin.

SeArs, LAurie J. 1996. Shadows of Empire: Colonial Discourse and Javanese Tales. Durham: Duke University Press.

SimUH. 1987. "Aspek Mistik Islam Kejawen dalam Wirid Hidayat Jati” UJavanist Muslim mystical aspects of the Wirid Hidayat Jati]. In Warisan Intelektual Islam Indonesia, edited by Ahmad Rafa'i Hasan. Bandung: Mizan.

- 1988. Mistik Islam Kejawen: Raden Ngabebi Ranggawarsita: Suatu Studi Terhadap Serat Wirid Hidayat Jati [Javanese Muslim mysticism: Raden Ngabehi Ranggawarsita: A study of the Serat Wirid Hidayat Jati]. Jakarta: University of Indonesia Press.

SOEBARDI, S. 1971. "Santri Religious Elements as Reflected in the Book of Tjentini." Bijdragen tot de Taal-, Land-en Volkenkkunde 127(3):331-49.

Soedjatmoko. 1965. "Cultural Motivations to Progress: The 'Exterior' and 'Interior' Views." In Religion and Progress in Modern Asia, edited by Robert N. Bellah. New York: Free Press.

Solahudin, Dindin. 1996. “The Workshop for Morality: The Islamic Creativity of Pensatren Daarut Tauhid in Bandung, Java." M.A. thesis, Australian National University, Canberra.

Stange, Paul. 1986. “'Legitimate' Mysticism in Indonesia." Review of Indonesian and Malaysian Affairs 20(2):76-117. 
SteEnbrink, Karel. 1996. "Recapturing the Past: Historical Studies by IAINStaff." In Toward a New Paradigm, Recent Developments in Indonesian Islamic Thought, edited by M. R. Woodward. Tempe: Arizona State University Program for Southeast Asian Studies.

Subagya, Rahmat. 1976. Kepercayaan-Kebatinan, Kerobanian, Kejiwaan-dan Agama [Faiths-mysticism, spirituality, spiritual psychology-and religion]. Yogyakarta, Indonesia: Penerbitan Yayasan Kanisius.

SyAFI'I, Ahmad. 1996. "Gerakan Tarekat Desekitar Muria" [Tarekat movements around Muria]. Tradisi di Tengab Akselerasi Modernisasi. Jakarta: Badan Penelitian den Pengembangan Agama, Departmen Agama R. I.

SyAm, Nur. 1998. "Tarekat Dalam Politik Lokal: Makna Afiliasi Politik Penganut Tarekat Oodiriyah Wanaqasyabandiyah" [Tarekats in local politics: Implications of the political affiliations of followers of the Tarekat Qodiriyah Wanaqasyabandiyah]. Gerbang, Trial Edition (July):40-46.

Syukur, H. M. Amin. 1999. Menggugat Tasawuf; Sufisme dan Tanggung Jawab Sosial Abad 21 [Challenging Tasawuf: Sufism and social responsibility in the twentyfirst century]. Yogyakarta: Pustaka Pelajar.

Tessler, M. A., and J. Jesse. 1996. "Gender and Support for Islamist Movements." Muslim World 86(2):200-28.

Thoy IBI, M.1996. Kaum Terpelajar dalam Tarekat Naqsyabandiyab di Yogyakarta dan Surakarta [Educated people in Tarekat Naqsyabandiyah in Yogyakarta and Surakarta]. Research Report. Surakarta: Universitas Muhammadiyah Surakarta.

Trimingham, J. S. 1973. The Sufi Orders in Islam. Oxford: Oxford University Press. Van Bruinessen, Martin. 1992a. "Pesantren dan Kitab Kuning: Pemeliharaan dan Kesinambungan Tradisi Pesantren" [Pesantren and "Yellow Books": Maintenance and continuity of the pesantren tradition]. Ulumul Qur'an 3(4):7385 .

1992b. Tarekat Naqsyabandiyah di Indonesia: Survei Historis, Geografis dan Sosiologis [Tarekat Naqsyabandiyah in Indonesia: A historical, geographical and sociological survey]. Bandung: Mizan.

- 1995. Kitab Kuning, Pesantren dan Tarekat: Tradisi-Traditi Islam di Indonesia ["Yellow Books," pesantren, and tarekat: Islamic traditions in Indonesia]. Bandung: Mizan.

Van Der Kroef, Justus M. 1961. "New Religious Sects in Java.” Far Eastern Survey 30(2):18-25.

Voll, John O. 1994. Islam, Continuity, and Change in the Modern World. Syracuse: Syracuse University Press.

Wiranto, Rihad, Asrori Karni, Sujoko, and Mujib Rahman. 2000. "Nikmatnya Mengapai Fana" [The joy of achieving Fana]. Gatra 46(6):http:// www.gatra.com/VI46/LKH3-46.ht.

WOODW ARD, M. R. 1989. Islam in Java: Normative Piety and Mysticism in the Sultanate of Yogyakarta. Tucson: University of Arizona Press.

- 1993. "Textual Exegesis as Social Commentary: Religious, Social, and Political Meanings of Indonesian Translations of Arabic Hadith Texts." Journal of Asian Studies 52(3):565-83.

— 1996. "Talking across Paradigms: Indonesia, Islam, and Orientalism." In Toward a New Paradigm: Recent Developments in Indonesian Islamic Thought, edited by M. R. Woodward. Tempe: Arizona State University Program for Southeast Asian Studies. 
Zoetmulder, P. J. 1995. Pantheism and Monism in Javanese Suluk Literature: Islamic and Indian Mysticism in an Indonesian Setting. Edited and translated by M.C. Ricklefs. Leiden: KITLV Press.

Zulkifli. 1994. "Sufism in Java: The Role of the Pesantren in the Maintenance of Sufism in Java." M.A. thesis, Australian National University, Canberra. 